\title{
Quest for self-reliance runs into trouble
}

New Delhi

SCIENTIFIC research in India is being steered by Prime Minister Rajiv Gandhi in a new direction intended to take the country into the twenty-first century - fast. Gandhi has made it clear that his government will not tolerate "rubbish science" or inefficient industry, and that all research must be productive. Indian scientists have been told not to waste time in reinventing technologies that can be purchased, but to work on those that others are not willing to sell. His adviser Mr L.K. Jha has gone a step further in suggesting that industries should not hesitate to import not only technologies but, if necessary, whole factories as well.

The plans for the overhaul of research and development and liberalized import policy stem from Gandhi's conviction that Indian scientists have been pampered for too long without being accountable and that industries have enjoyed protection for years at the cost of efficiency. Scientists are now being asked to deliver and industries to compete and catch up. "India had been pushing hard on science while neglecting the technology aspect", Gandhi told a recent press conference. "Our research and development must be such that it really ends up with a finished product." Gandhi feels that India's 750 million people are entitled to a better deal from Indian technologists. Since they have failed, there should be no objection to importing foreign technology.

The Council of Scientific and Industrial Research (CSIR) is the first agency to be asked to streamline its research. Other ministries that preside over research establishments will follow. Gandhi has directed CSIR to concentrate on a few key areas or "technology missions ... instead of frittering away energy on a whole gamut of fields." Following Gandhi's directive, CSIR director general Dr S. Varadarajan has undertaken the massive exercise of revamping the research activities of the council's 40 or so institutes. Several CSIR projects that lack definite goals are to be axed and pilot plants that have failed to generate interest in industry may be scrapped. About half of CSIR research is related to developing "import substitutes". Now that import is freely allowed, such projects will face closure. Basic research will be a casualty. As far as CSIR is concerned, the only basic research permitted is that relating to "frontier areas" such as biotechnology or microelectronics.

Not everybody in CSIR is happy about the shape of things to come. "Our Prime Minister wants us to leapfrog to the twenty-first century". says a senior scientist. "But we cannot get there without mastering twentieth century technology." Although a month has passed since the review began, few technology "missions" have been identified. "We can easily close down unproductive projects", says Varadarajan, "but it is not easy to replace them with new ones." CSIR has about 20,000 scientists and technicians, and it is an open question how to relocate those whose projects are to be axed. In the past. Indian industry has been more or less forced to adopt CSIR technology. According to one CSIR director, requests for processes from his laboratory dropped from 77 in 1984 to four in 1985. It is feared that with industries free to import the best from abroad there will be no more takers for CSIR knowhow.

The liberalized policy on the import of technology has also come under attack from sections of the scientific community inside and outside CSIR, as is shown by recent controversies over the move to import silicon and fibre optics technology. Critics believe the import policy is a negation of self-reliance, the hallmark of Indian science during the days of Jawaharlal Nehru and Indira Gandhi. "Indian research and development has been castrated", says Baldev Singh, former chief of the technology utilization division of CSIR. "The country's laboratories appear almost like condemned institutions", says Mr P.S. Deodhar of the Electronics Trade and Technology Development Corporation. There is a fear that industries based on indigenous technologies will be wiped out and that CSIR will face a slow death.

The fear is not unjustified. A cottage industry making silicon-carbide crucibles, and a factory that just started making "chlorosilane" using CSIR technology are facing closure as these products can now be freely imported. CSIR spent eight years developing SWAT-106, a chemical that improves oil flow through pipelines. But now four multinationals are planning to bring in their own technologies for a flow improver.

The Hindustan Times in a leading article said: "More and more public undertakings are hankering after foreign deals little bothering to find out whether appropriate indigenous knowhow exists. What is the idea of having big scientific establishments if their talents cannot be utilized locally?"

In the electronics sector, the clamour for foreign collaboration is at its peak. According to Deodhar, the import policy is luring businessmen "whose motive is commercial rather than technical". Consumer electronics items with international brand names are being marketed by Indian companies that have sprung up overnight. Some 29 giant computer companies from abroad are planning to enter the market, virtually sealing the fate of the state-owned Electronics Corporation of India Limited.

According to Prem Shanker Jha, a noted economist, the present import policy has spawned literally hundreds of "screwdriver units" in the electronics and automobile industries, "the two potentially biggest customers of capital goods industries". There are three foreign collaborations for passenger cars, 10 for commercial vehicles and 14 for scooters and motor cycles. The government-owned Maruti car factory has rejected an Indian consortium's offer to set up an engine production line in favour of a Japanese company. Britain is setting up a plant near Bombay that will make 12,000 electric vehicles a year, preempting the electric vehicle project of the public sector Bharat Heavy Electricals Limited (BHEL), which is itself purchasing anticorrosion technology from a US company, ignoring processes developed by a CSIR institute.

"From one extreme of self-reliance, the pendulum has swung to the other", says Baldev Singh, "and many of the current imports in the name of high-tech are really irrelevant to taking India into the twentyfirst century." Meanwhile, the number of foreign collaborations shot up from 440 in 1984 to 752 in the first six months of 1985 and foreign exchange reserves dipped from $£ 4,800$ million in April to $£ 480$ million by the end of July.

The peculiar situation in Indian science today is that heads of scientific agencies who privately worry about the technology import policy publicly remain silent or defend it. Many agree that the 1982 technology policy statement (TPS), which warned against indiscriminate import, has now been more or less torn to pieces. But Professor M.G.K. Menon, planning commission member and architect of TPS, will not comment on the new policy. And Rajiv Gandhi's government still swears by TPS. "The government has not deviated from the concept of economic self-reliance and the liberalized policy of import will not throttle indigenous research or industry", the Prime Minister recently told newsmen. But sceptics, including the president of the Indian National Science Academy $\mathrm{Dr}$ C.N.R. Rao, who strongly opposed import of silicon technology, still believe that liberalized imports will stifle indigenous research.

Professor Abdul Rahman, a former CSIR director and science policy specialist, has warned that modernization cannot be achieved with imports of technology. "This", he said, "has been amply demonstrated in Latin America which is saddled with debt, and in Iran where the Shah's hurry to modernize with massive technology inputs led only to political crisis."

K.S. Jayaraman 